UDC 658.8:004.7

DOI https://doi.org/10.30839/2072-7941.2018.155564

\title{
DIRECTIONS OF INDUSTRIAL MANAGEMENT EFFICIENCY IMPROVING WITH USE OF INFORMATION RESOURCES
}

\author{
C SERGIENKO T.I. \\ Engineering institute of Zaporizhzhya national University (Zaporizhzhia, \\ Ukraine)
}

E-mail: Sergienko7921@gmail.com, ORCID 0000-0002-4654-9248

(C) KRAYNIK O.M.

Engineering institute of Zaporizhzhya national University (Zaporizhzhia, Ukraine)E-mail: elenakrainik2@gmail.com, ORCID 0000-0002-9787-0744

\begin{abstract}
The urgency of the research topic is that the directions of increasing of industrial management in modern conditions are presented. The way in which the production process of an enterprise is managed depends on its efficiency, profitability and competitiveness in a market economy. Problem statement - analysis of various directions of increasing of the efficiency of industrial management with the use of information resources; Assessment of the role and significance of the production potential of the enterprise in the social production. Analysis of recent researches and publications - in the article the analysis of the main provisions of the theoretical substantiation of the directions of increasing the efficiency of industrial management, which are reflected in the works of national scholars G.Osovska, V.Voronkova, R.Fathutdinova, N.Podolchak, A.Shegda, are presented. The methodological foundation for conducting of research on selected topics was the works of leading scientists, specialists, the study of indicators for improving the efficiency of the enterprise was carried out by I. Boychik, O. Hetman, I. Kovalchuk, S.Pokropivny, Y.Ponomarev, V.Sidoun, V.Shapoval and others. Selection of unexplored parts of the general problem is conducted on the basis of unpredictability of modern economic conditions of enterprises, which requires further research and identification of the real ways of stabilization and possible increase in the efficiency of enterprises. Methodology - system, structural, structural and functional analysis, which allowed analyzing problems of directions of increasing the efficiency of industrial management with the use of information resources. Presenting of the main material. The article analyzes the production potential of the enterprise. The questions of measuring the magnitude and level of efficiency of the use of production potential by means of the use of modern methods on the basis of research of the leading methodologies are considered. It is proved that the idea of the magnitude of the production potential of the enterprise and its individual elements allows to some extent to manage the characteristics of the potential, resulting in the possibility of a targeted effect on the return of production resources. Conclusions - the research has shown that under the reserves of increasing the economic efficiency of production, they understand the unused opportunities for increasing output in terms of unit costs due to rational use of all types of enterprise resources.
\end{abstract}

Keywords: Potential, production, enterprise, industry, indicators, elements, evaluation, principles, stages, industrial management, information resources.

Directions of industrial management efficiency improving with use of information resources 
Statement of the problem in general and its connection with important scientific or practical tasks Today's realities indicate that the state's economy is characterized by a decline in production volumes and incomplete utilization of production capacities. In a number of industries, this situation caused the loss of production capacity of the enterprise. In the management of enterprises there is a shift in emphasis on the management of individual resources and the relevant functional units on the management of cross-cutting business processes, which bind together the activities of the interrelated divisions of the enterprise. Consequently, the economic conditions in which enterprises carry out their activities have changed in a concrete way today, which has led to the formulation of target facilities. On the one hand, enterprises are provided with economic independence, they themselves decide on the purchase and sale of products, the definition of scale production and the direction of using sources of funds. On the other hand, it is specific for these enterprises a high degree of deterioration of the active part of fixed assets, low level of labor productivity, quality of products, and as a result unsustainable financial position. [9, c. 48].

Thus, the study of the directions of industrial management with the use of information resources, aimed at finding ways to use it more efficiently, is becoming more and more relevant, and this problem becomes a national economic significance.
Analysis of recent research and publications. Some aspects of this problem are considered in the works of foreign and domestic scholars such as M. Meskon, M. Albert, F. Hedouri, G. Goldsthein, M. Hammer, Z. Kovachev, S.Golovny, A.Anchyshkin, L.Sosnenko, V.Vasilenko, A.Aganbegyan, A.Semenov, B.Plishevsky, G.Sorokin, N. Khrushch, Y. Donets, O. Fedonin, I. Repina, O. Oleksik and others. Theoretical and practical studies directly relate to the place and role of productive capacity in production.

Unsolved earlier parts of the general problem. In scientific works on the problems of the formation and implementation of the potential of enterprises is usually not enough developed the question of measuring its size and the level of efficiency of use. The purpose of the research consequently, the purpose of this study is to analyze the production potential in the production, to determine the assessment of the potential and justify the scope of application of production potential. This goal is realized in the following tasks:

- to investigate the problems of forming the potential of the enterprise;

- develop ways to increase the efficiency of industrial management with the use of information resources;

- to assess the potential of the enterprise.

Object of research - directions of increase of efficiency of industrial management.

Subject of research - socioeconomic laws that affect the efficiency of industrial management. 
Presenting of the main material. Thus, before proceeding to the discussion of the problem, it should be noted that the production potential of the enterprise characterizes the resources that are separated in the main economic unit, therefore, it is less productive potential of the industry and the economy, and is their component as a part of the whole[10, c. 107]. The listed potentials are dependent, so, the industrial potential of the industry is defined as the sum of the production potential of the incoming companies in it, and the potential of the national economy is the accumulation of potential industries.

The role and significance of the productive potential of the enterprise in the social production does not remain unchanged. The production potential of the enterprise is a material precondition for accelerating scientific and technological progress. Between them there is a relationship - the higher the techno-economic level of the elements of the potential and the degree of their use, the more powerful base (logistical) of scientific and technological progress, the wider horizons of its implementation, more opportunities to improve and increase the size of elements of production potential industrial enterprise. They mutually improve and develop each other.

At the same time, the production potential of the company is directly related to the pace of socio-economic development of the country. Improving its use contributes to the growth of production of investment resources and consumer goods at the same costs of social work. And its qualitative characteristics determine the degree of satisfaction of material and spiritual needs of the people and the very quality of economic and social growth.

Being the main link of the national economic complex, the enterprise concentrates on itself all resources of production.

The increased complexity dictated the need to remove routine settlement functions from a person, taking advantage of the potential of computer technology and thus allowing management personnel to concentrate on the adoption of managerial decisions. Thus, two trends were combined: a methodological decision of the tasks of control and application of computer technology to support the solution of these tasks [5].

Under current conditions, a business process as a set of interconnected operations for the production of finished products or the provision of services based on consumption of resources is a fundamentally important element of quality customer service. At the same time during the management of business processes, all material, financial and information flows are considered in interaction. Today, reengineering of business processes as a method of fundamental restructuring of business processes in order to achieve a qualitatively different, higher level of indicators of production and economic activity of the enterprise; is used as a comprehensive means of reorganizing an enterprise or its separate structural units. 
The purpose of reengineering business processes is the systematic restructuring of material, financial and information flows, aimed at simplifying the organizational structure, redistributing and minimizing the use of various resources, reducing the timing of customer needs, improving their service quality [16].

In scientific literature one of the first concepts of "production potential" was used by O. Arefyeva and T. Kharchuk, including "a set of resources that in the process of production take the form of factors of production" [2, p. 14].

This approach to the concept of productive potential has become widespread among researchers. There are two "resource" positions. The first - the production potential is a combination of resources without taking into account their interconnection and participation in the production process [3, c. 201]. The peculiarity of the second position is the treatment of production potential as a combination of resources capable of carrying a certain amount of material wealth.

Along with the resource approach to determining the nature of the production potential, there are other interpretations. Thus, Y. Donets considers production potential to be synonymous with the production capacity of an enterprise, an association, and therefore it is possible to define it as "the maximum possible annual, daily, hourly or other output of a temporary unit, the concept is territorial and extends to a set of productions common in a certain area" $[14$, c.3]. According to E. Vorobyov, production potential is a real volume of production, which the economy is able to produce when full use of available resources [4, c.363].

Proceeding from these concepts, the production potential includes various resources: sometimes they refer only to productive assets and capacities, sometimes the production potential includes production funds and skilled workers of the working people, sometimes productive capacity includes productive funds , resources management and production organization, personnel, scientific and technical information.

The purpose of the implementation of such resources is to achieve the marginal and integrated efficiency of the production system. In other words, to obtain the maximum possible result in terms of production volume, product quality, cost, delivery time, job security and personnel initiative with minimal use of resources human, material, financial.

The analysis of the above points of view leads to the conclusion that the production potential of the economic system is a set of resources provided at its disposal for creative activity. Quantitative and qualitative parameters of these resources, as well as their integration, determine the production capacity of the economic branch. However, the production potential, determining the possibility of producing material goods and services, cannot serve as a measure of beneficial effect.

The main value of the production potential of the company is to create new values, and its elements must 
purposefully adapt to the requirements of manufactured products. This is its purpose, it will be able to perform it, if the accepted real physical form and the quantitative proportion of its components make it able to function as a value that creates value and added value. That is, when the composition and characteristics of the elements of the production potential are consistent and are determined by the parameters of the manufactured products.

In this case, all the elements of the production potential are one of the common goals of the enterprise. But precisely that the place and functions of each element are determined by the requirements imposed on the totality of elements in general, and characterize its ordering. On the other hand, the implementation of a set of elements of the general for the production potential of the task means that they are interconnected and interact with each other. Thus, the production potential meets the requirements of the systems.

The main task of production potential lies in the production of products, that is, in its reproduction. It is obvious that in order for the production potential to be able to carry out this continuous process, it must also continuously and continuously reproduce itself. Production potential must have the ability to reproduce itself. In practice, this ability is confirmed by a number of trends: a system of repairs and modernization of fixed assets of the enterprise. Another form of practical realization of the capacity of production potential to selfreproduction should be considered an increase in the structure of industry, the number of enterprises.

Some economists have come to the conclusion that the assessment of enterprises must be comprehensive [4, P.6]. The specificity of the integrated assessment lies in the fact that it is obtained through the harmonization of the results of a comprehensive economic analysis. It contains generalized conclusions about the activity of the object, which are based on the principle of systemicity. L.Mikhalyuk recommends that the evaluation process should be considered by the following main elements:

- object of evaluation;

- subject of assessment

- criterion; indicator (system);

- unit (scale) of measurement;

- assessment [6, C.4].

The main elements are in each other in an appropriate connection and in appropriate relationships. The evaluation process also takes place in a certain sequence and requires a clear organization. Taking into account these requirements, a mechanism for assessing the potential of the enterprise has been developed. The assessment provides an opportunity to establish how the company works, or achieve the goals set, as changes and improvements in the management process affect the completeness of the company's potential utilization and its effectiveness.

Continuous changes taking place in the economy dictate the need for constant updating of knowledge of enterprises and organizations as intellectual capital, ensuring stable strategic positions of enterprises in the 
market, effective adaptation to changing environment conditions. A new management function is being formed, and its tasks include the accumulation of intellectual capital, the identification and dissemination of available information and experience, and the creation of prerequisites for the dissemination and transfer of knowledge. It is knowledge that becomes a source of high productivity, innovation and competitive advantage. Knowledge management is characterized by the collective formation and use of internal and external sources of knowledge (information resources), the creation of computer knowledge management systems, etc.

Some economists believe that there is a single synthetic (integral) indicator. At the same time, in their view, the mandatory condition should be the construction of partial indicators to the general. But there are other views pointing to the shortcomings of the integral indicators and their ineffectiveness for practical use.

In our opinion, a comprehensive system of indicators is needed to assess the company's potential, and a structural model based on the design of such a system should be based on which takes into account not only the actual dynamics but also the theoretical preconditions. The structural model of the system of indicators should conceptually take into account the following requirements for its formation (Figure $1)$ :

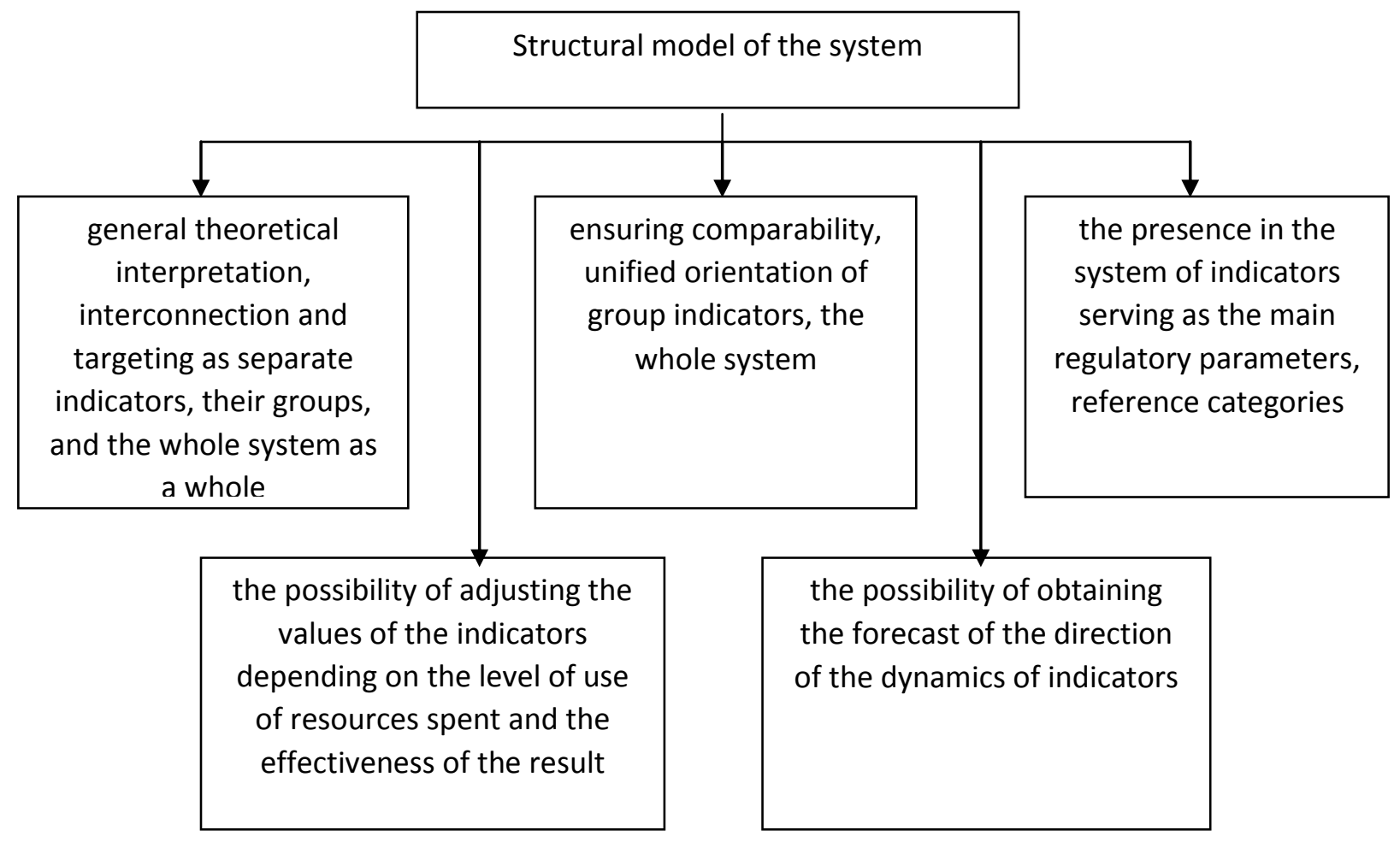

Figure 1. Structural model of the system

It should be noted that the set of appraisal principles, indicators, for evaluation. In general, evaluation criteria and methods is a methodology sequence of actions: the formation of (C) Sergienko T. I., Kraynik O. M., 2018 
categories, the development of indicators, the establishment of the criterion of comparison; choice of method of assessment, obtaining the result of evaluation.

Based on the definition of the concept of potential enterprise, the assessment of its value can be defined as the sum of the actual values of the components. But this fact raises the question: in which indicators must these components be measured? The use of natural indicators is too complicated, since the elements of the potential vary considerably from one another in terms of content and form. In this regard, the natural units that characterize them are also different. Therefore, many researchers consider the best measurements of the values of potential elements using one indicator-equivalent. For example, agrarian potential is proposed to measure the cost of reproduced resources, while productive assets are taken into account according to their reproduced estimates, and labor and natural - are estimated, according to which the unit of non-reproductive resource is replaced by a certain amount of production funds. Some recommend estimating the physical volume of the elements of the potential of the enterprise due to the number of industrial and production personnel. But most researchers believe that the most versatile measure of the elements of a company's potential are cost units. In this case, the sum of the elements of the cost will characterize the size of the entire potential of the enterprise. Consequently, determining the size of the potential of the industrial enterprise is associated with the assessment of the cost of its elements. However, this method is not as universal as it seems at first glance. Determine the value of fixed assets and working capital is quite easy, but it is possible to estimate the labor resources only indirectly and to a large extent conditional, since for quality labor the decisive factor is the quality of labor. The quality of work or the level of its complexity are determined by knowledge, practical skills and other human features, such as dexterity, the ability to perform complicated operations that are not directly measurable.

Therefore, it is advisable to characterize the potential of an enterprise not one but a set of indicators, and, depending on the nature of the indicator itself, either a valuation, or a natural or a completely different, heuristic. The methodological basis for their definition is the ratio of the result to the weight of the resource used to achieve it. At the same time, indicators of the level of use of the potential elements should make it possible to compare the efficiency of the use of various elements of the potential of one enterprise and different production systems. Estimating the value of a company's potential is an orderly, purposeful process of determining the value of an asset in terms of money, taking into account the potential and actual income that takes place at a certain time in a specific market. In assessing the potential of the enterprise are interested the following: lenders; investors: the state; shareholders; 
managers; suppliers; insurance determine the main goals of companies [16, c. 89-93]. They want evaluation, namely (Figure 2):

to realize their economic interests and

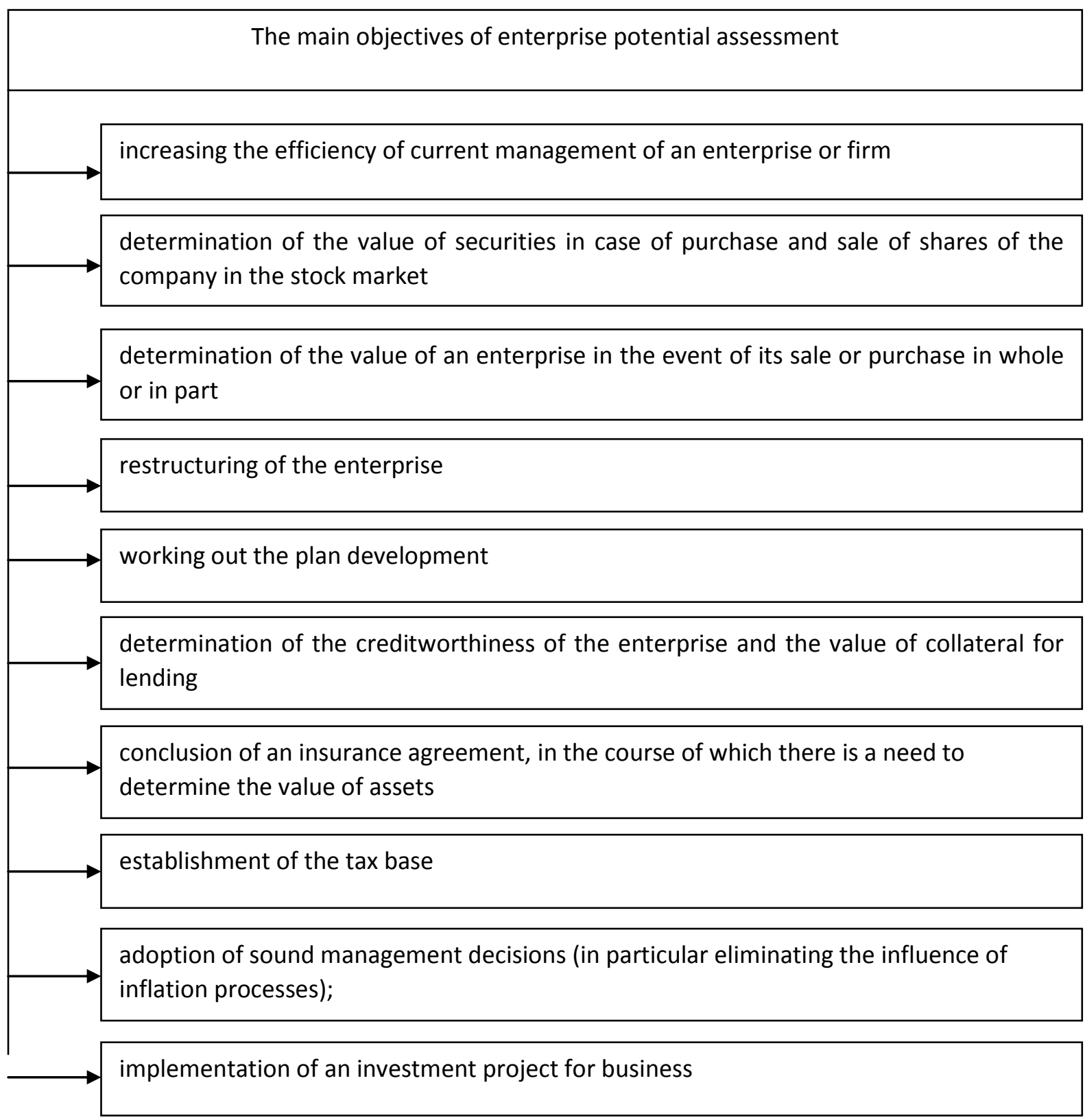

Figure 2. Objectives of enterprise potential assessment

Conclusions. Summing up, it should be noted that the problem of measuring the magnitude of production potential is very important both in the theoretical and practical terms. Knowledge of production potential of enterprises allows determining the total potential of economic or sectoral rates and (C) Sergienko T. I., Kraynik O. M., 2018

industry and national economy, creates the basis for ensuring the connectivity of related enterprises and industries. The value of production potential of enterprises is necessary to identify the costs of production resources needed to optimize the 
proportions of the development of defining the directions of investment policy. The magnitude of the production potential is a characteristic of the material conditions for updating the product and improving its quality and can be the basis for predicting the volumes of industrial production. Production potential as an indicator of resource potential plays a large informative role. With the help of this kind of complex indicators, the contradictions arising in the evaluation of the multidirectional motion forming its elements are eliminated. The ratio of the value of the potential to the end result of the operation gives a comprehensive view of the degree of use of production resources and reserves to increase the efficiency of production. In the presence of these data, the possibility of a more objective definition of the directions of optimization of the structure of the potential and ways of its further building up. The goal of the near future will be to form business methods that can customize products and create individual values that in turn will allow to obtain specific, efficient and cost-effective tools for the creation of the end product. The ability of producers to synchronize individual consumer needs with their production system and planning will become a critical factor in success. However, in order to achieve this level, appropriate information support of all stages of the product life cycle is required. Indicators of the estimation of the size of the potential can find application in the system of taxation of the enterprises. There is a promising opportunity to use indicators of production potential in stimulating the work of managers and specialists in the business units, as well as to create a system of conditional assessments of enterprises and industries. Thus, the magnitude of production potential and its structure may have a wide range of use in planning, forecasting and stimulating material production.

The idea of measuring the potential as the highest returns of aggregate resources is very attractive. However, there are a number of practical problems on this path: the elements of the potential differ considerably from one another both in terms of content and form. In this regard, various and natural units that characterize them. Aggregation of different qualitative characteristics becomes possible only if we can find a general principle of evaluation, measurement, which allows us to express a variety of qualities. The most unified and measuring element of the production potential is their price or value. The convergence of the indicators of the potential in monetary evaluation in time and space allows us to identify the dynamics and structure of the production potential of enterprises and territorial entities, the differences and trends in their differentiation by indicator, as well as on the efficiency of the use of production potential. The sum of the elements' values will characterize the size of the entire production potential of the enterprise. Prospects for further research - the study of improving the efficiency of the management system in the manufacturing sector in enterprises in 
a market economy and reserves to increase the efficiency of production as a component of the economy of Ukraine.

\section{REFERENCES}

1. Anthony, R., Govindarajan, V. (2007). Management Control Systems. Chicago: McGraw-Hill IRWIN, 784.

2. Arefieva, O. V., Kharchuk, T. V. (2008). Ekonomichni zasady formuvannia potentsialu pidpryiemstva. Aktualni problemy ekonomiky, 7, 71-76.

3. Vasylenko, V. O. (2003). Antykryzove upravlinnia pidpryiemstvom. Kyiv: TsUL, 504.

4. Vorobiov, Ye. M. (2005). Ekonomika. Dovidnyk starshoklasnyka ta abiturienta. Kharkiv: TORSINH PLIuS, 400.

5. Kraynik, O. (2015). Improving marketing activities via external investment in LLC "Ice Zaporozhye". Chasopys ekonomichnykh reform, 2 (18), 85-90.

6. Kraynik, E. (2015). Risk management as a tool for regulating economic behavior of industrial enterprises in the contemporary economy. Investytsiyi: praktyka ta dosvid, 10, 2831.

7. Mykhaliuk, L. M. (2013). Teoretychni aspekty formuvannia ekonomichnoi efektyvnosti ta systema pokaznykiv yii otsinky. Visnyk Zhytomyrskoho natsionalnoho ahroekolohichnoho universytetu, 1-2 (2), 75-81.

8. Pokropyvnyi, S. F. (2011). Ekonomika pidpryiemstva. Kyiv: KNEU, 528.

9. Punchenko, O. P., Voronkova, V. H., Andriukaitiene, R. (2018). Sociodynamics of the globalizing world in its civilization dimension. Humanities Bulletin of Zaporizhzhe State Engineering Academy, 74, 48-60. doi: https://doi.org/10.30839/2072-7941.2018.149652

10.Sergienko, T. (2013). Measurement velychyn and efficiency using level building is industrial enterprises. Humanities Bulletin of Zaporizhzhe State Engineering Academy, 52, $107-113$.

11.Sergienko, T. (2012). Human resources management at the enterprise in the modern ystem of management. Humanities Bulletin of Zaporizhzhe State Engineering Academy, 51, $101-107$.

12.Sprinsian, V. H., Biriukova, T. L. (2012). Resursy ta tekhnolohiyi informatsiinoho menedzhmentu. Odessa: ONPU, 248.

13.Streltsova, S. M. (2011). Analiz pidvyshchennia efektyvnosti vyrobnytstva suchasnykh pidpryiemstv. Visnyk sotsialno-ekonomichnykh doslidzhen, 2 (42), 348-355.

14.Ustenko, S. V., Bereza, A. M., Haluzynskyi, H. P. et. al. (2012). Informatsiyni systemy v ekonomitsi. Kyiv: KNEU, 425.

15.Fedonin, O. S., Riepina, I. M., Oleksyk, O. I. (2003). Potentsial pidpryiemstva: formuvannia ta otsinka. Kyiv: KNEU, 316.

16. Hammer, M., Champi, D. (2006). Reinzhiniring korporacii: Manifest revolyucii v biznese. Moscow: Mann, Ivanov i Ferber, 287.

17.Shliaga, O., Gal'tsev, M. (2014). The ways of the enterprise' efficiency increasing. Ekonomichnyi visnyk Zaporizkoi derzhavnoi inzhenernoi akademiyi, 7, 66-75.

СЕРГІСНКО Т. І. - кандидат політичних наук, доцент кафедри Менеджменту організацій та управління проектами, Інженерний інститут ЗНУ (Запоріжжя, Україна)

E-mail: Sergienko7921@ gmail.com, ORCID 0000-0002-4654-9248

КРАЙНІК О. М. - кандидат економічних наук, доцент кафедри Менеджменту організацій та управління проектами, Інженерний інститут ЗНУ (Запоріжжя, Україна)

E-mail: elenakrainik2@gmail.com, ORCID 0000-0002-9787-0744 


\section{НАПРЯМИ ПІДВИЩЕННЯ ЕФЕКТИВНОСТІ ПРОМИСЛОВОГО МЕНЕДЖМЕНТУ 3 ВИКОРИСТАННЯМ ІНФОРМАЦЙНИХ РЕСУРСІВ}

Анотація. Актуальність теми дослідження в тому, що представлено напрями підвищення промислового менеджменту в сучасних умовах. Від того, яким чином буде здійснюватися управління виробничим процесом підприємства, залежить його ефективність, прибутковість та конкурентоспроможність в умовах ринкової економіки. Постановка завдання - аналіз різноманітних напрямів підвищення ефективності промислового менеджменту з використанням інформаційних ресурсів; оцінка ролі і значення виробничого потенціалу підприємства в суспільному виробництві. Аналіз останніх досліджень і публікацій - в статті представлено аналіз основних положень теоретичного обгрунтування напрямів підвищення ефективності промислового менеджменту, які знайшли своє відображення у роботах вітчизняних науковців Г.Осовської, В.Воронкової, Р.Фатхутдинова, Н.Подольчак, А.Шегди. Методологічним фундаментом здійснення дослідження обраної тематики стали праці провідних вчених, фахівців, науковців, зокрема дослідженням показниківпідвищення ефективності роботи підприємства займалися I Бойчик, О.Гетьман, І.Ковальчук, С.Покропивний, Ю.Пономарьова, В.Сідун, В.Шаповал та інші. Виділення недосліджених частин загальної проблеми - проведено на основі непередбачуваності сучасних економічних умов діяльності підприємств, що потребує подальшого дослідження і визначення реальних шляхів стабілізації та можливого підвищення ефективності роботи підприємств. Методологія - системного, структурного, структурно-функціонального аналізу, що дозволили проаналізувати проблеми напрямів підвищення ефективності промислового менеджменту 3 використанням інформаційних ресурсів. Виклад основного матеріалу. В статті проаналізовано виробничий потенціал підприємства. Розглянуто питання вимірювання величини i рівня ефективності використання виробничого потенціалу за допомогою використання сучасних методик на основі дослідження провідних методологій. Доведено, що уявлення про величину виробничого потенціалу підприємства і окремих його елементів дозволяє до певної міри управляти характеристиками потенціалу, внаслідок чого виникає можливість цілеспрямованої дії на віддачу виробничих ресурсів.Висновки - Провівши дослідження доведено, що під резервами підвищення економічної ефективності виробництва розуміють невикористані можливості збільшення випуску продукції в розрахунку на одиницю сукупних витрат завдяки більш раціональному використанню усіх видів ресурсів підприємства.

Ключові слова: потенціал, виробництво, підприємство, промисловість, показники, елементи, оцнка, принципи, етапи, промисловий менеджмент, інформаційні ресурси.

СЕРГИЕНКО Т. И. - кандидат политических наук, доцент кафедры менеджмента организаций и управления проектами, Инженерный институт ЗНУ (Запорожье, Украина)

E-mail: Sergienko7921@ gmail.com, ORCID 0000-0002-4654-9248

КРАЙНИК А. Н. - кандидат экономических наук, доцент кафедры менеджмента организаций и управления проектами, Инженерный институт ЗНУ (Запорожье, Украина)

E-mail: elenakrainik2@gmail.com, ORCID 0000-0002-9787-0744

\section{НАПРАВЛЕНИЯ ПОВЫШЕНИЯ ЭФФЕКТИВНОСТИ ПРОМЫШЛЕННОГО МЕНЕДЖМЕНТА С ИСПОЛЬЗОВАНИЕМ ИНФОРМАЦИОННЫХ РЕСУРСОВ}

Аннотация. Актуальность темы исследования в том, что представлено направления повышения промышленного менеджмента в современных условиях. От того, каким образом будет осуществляться управление производственным процессом Directions of industrial management efficiency improving with use of information resources 
предприятия, зависит его эффективность, прибыльность и конкурентоспособность в условиях рыночной экономики. Постановка задачи - анализ различных направлений повышения эффективности промышленного менеджмента с использованием информационных ресурсов; оценка роли и значения производственного потенциала предприятия в производстве. Анализ последних исследований и публикаций - в статье представлен анализ основных положений теоретического обоснования направлений повышения эффективности промышленного менеджмента, которые нашли свое отражение в работах отечественных ученых Г.Осовськои, В.Воронковои, Р.Фатхутдинова, Н.Подольчак, А.Шегды. Методологическим фундаментом проведения исследования выбранной тематики стали труды ведущих ученых, специалистов, ученых, в частности исследованием показникивпидвищення эффективности работы предприятия занимались И Бойчик, О.Гетьман, И.Ковальчук, С.Покропивний, Ю.Пономарьова, В.Сидун, Шаповал и другие. Выделение неисследованных частей общей проблемы - проведено на основе непредсказуемости современных экономических условиях деятельности предприятий, что требует дальнейшего исследования и определения реальных путей стабилизации и возможного повышения эффективности работы предприятий. Методология - системного, структурного, структурно-функционального анализа, позволили проанализировать проблемы направлений повышения эффективности промышленного менеджмента с использованием информационных ресурсов. Изложение основного материала. В статье проанализированы производственный потенциал предприятия. Рассмотрены вопросы измерения величины и уровня эффективности использования производственного потенциала с помощью использования современных методик на основе исследования ведущих методологий. Доказано, что представление о величине производственного потенциала предприятия и отдельных его элементов позволяет в определенной мере управлять характеристиками потенциала, в результате чего возникает возможность целенаправленного воздействия на отдачу производственных ресурсов. Выводы - Проведя исследования доказано, что под резервами повышения экономической эффективности производства понимают неиспользованные возможности увеличения выпуска продукции в расчете на единицу совокупных затрат благодаря более рациональному использованию всех видов ресурсов предприятия.

Ключевые слова: потенциал, производство, предприятие, промышленность, показатели, элементы, оценка, принципы, этапы, промышленный менеджмент, информационные ресурсы.

Стаття рекомендована до публікачії д.економ.н., проф. А.В. Череп (Запоріжжся, Україна)

Надійшла до редколегіі: 07.12.2018 p Прийнята до друку: 12.12 .2018 p.

(C) Sergienko T. I., Kraynik O. M., 2018 